\title{
CONTRACEPTIVOS DE EMERGENCIA E ABORTO NO DIREITO PENAL BRASILEIRO: UMA ANÁLISE BIOÉTICA
}

\author{
Helio Veiga Junior ${ }^{1}$ \\ Patricia Borba Marchetto ${ }^{2}$
}

\begin{abstract}
Resumo
O presente artigo procura analisar a relação entre a liberdade feminina e o direito à vida, com um estudo sobre os efeitos dos contraceptivos de emergência como o Levonorgestrel e o Acetato de Ulipristal, em uma análise bioética sobre o teor biológico, social e jurídico trazido pelos fármacos mencionados. Não obstante, analisa-se as teorias da personalidade vinculadas aos efeitos dos contraceptivos de emergência para se chegar a uma ideia se estes seriam meros métodos contraceptivos de emergência ou abortivos. No que se refere à análise feita pelas teorias da personalidade, o estudo aqui realizado busca solucionar a colisão de princípios existente quando se tem de um lado a vida e de outro a liberdade substancial feminina, sopesando tais princípios caso a caso. Ademais, o presente estudo procura trazer uma análise de como a criminalização do aborto é prejudicial, e assim, ineficaz, à realidade brasileira, uma vez que a sociedade feminina busca por sua emancipação social quanto à questões relativas ao próprio corpo como uma forma e efetivar o direito à saúde, especialmente a saúde pública. Apresentase aqui a realidade brasileira que ainda conta com o uso do fármaco Cytotec que mesmo banido do Brasil ainda pode ser encontrado e adquirido ilegalmente no mercado paralelo. Por último, por meio da abordagem dedutiva, busca-se analisar possíveis efeitos cíveis que seriam causados pelo aborto, com a finalidade de defender sua descriminalização.
\end{abstract}

Palavras-chave: Levonorgestrel. Acetado de Ulipristal. Aborto. Liberdade. Vida.

\section{INTRODUÇÃO}

O mundo contemporâneo em que a sociedade se encontra não é mais o mesmo em termos de cultura, costumes, crenças, e, sobretudo, de relacionamentos interpessoais. Em um passado relativamente próximo era possível perceber o quanto as relações humanas urgiam um paradigma de comportamento baseado na conhecida

\footnotetext{
${ }^{1}$ Mestre em Direito pela Universidade Estadual Paulista - UNESP. Membro do Grupo - Observatório de Bioética e Direito da Universidade Estadual Paulista Júlio de Mesquita Filho - UNESP. Professor no Curso de Bacharelado em Direito da Faculdade de Ciências Humanas e Sociais - FACIHUS na Fundação Carmelitana Mário Palmério - FUCAMP. E-mail: helioveiga.law@gmail.com

${ }^{2}$ Doutora em Direito pela Universidad de Barcelona (2001), com título reconhecido pela Faculdade de Direito da USP. Professora na graduação e pós graduação da Universidade Estadual Paulista Júlio de Mesquita Filho (UNESP). Membro do Centro de Estudos e Práticas Pedagógicas da UNESP (CENEPP - UNESP). Tutora de grupo de Educação Tutorial (PET - Administração Pública/UNESP), vinculado ao MEC-SESu. Lider do Grupo de Pesquisa - Observatório de Bioética e Direito da Universidade Estadual Paulista Júlio de Mesquita Filho - UNESP.E-mail: pmarchetto@fclar.unesp.br
} 
moral e bons costumes. ${ }^{3}$

A sociedade como um todo procurava se pautar em conceitos morais cujas bases se vinculavam à uma moralidade religiosa não complacente com costumes que fugissem das regras dogmáticas de determinada religião, o que fazia com que os indivíduos, enquanto atores sociais, temessem possuir relações interpessoais desprovidas de vínculos duradouros.

De fato, a ideia de vida, imagem, honra, respeito, afeto, responsabilidade, durabilidade, compromisso, entre outras noções, perderam grande parte de seu sentido ao fazer a portabilidade social para a pós-modernidade, ou seja, um novo momento capaz de transformar tudo o que era visto como certo e dentro da moral e dos bons costumes em algo obsoleto e desnecessário uma vez que a contemporaneidade trouxe a velocidade e o desejo de intensificação da sociabilidade pós-moderna.

Sabe-se que em tempos de outrora o ato sexual fora visto enquanto uma promiscuidade se extrapolasse sua função sacra e quase social, ou seja, meramente reprodutora, já que a busca do sexo pelo mero prazer sem finalidades procriatórias se constituía como um ato vergonhoso capaz de trazer desonra à mulher que arriscasse praticar conjunção carnal antes do casamento, ou até mesmo depois, mas com o objetivo de se atingir o mero prazer sexual.

Inobstante a tal fato, por muitos anos, absurdamente, a mulher e sua virgindade foi vista enquanto propriedade privada, chegando a possuir no passado o condão de buscar um casamento e atualmente possui o poder comercial de ser mercantilizada em razão da sua importância social e cultural, ou seja, a virgindade, que antes era uma forma de se garantir a constituição de uma família para a filha mulher, hoje se tornou uma forma de se locupletar, e, de fato, licitamente.

Desta feita, a mulher havia se tornado, socialmente, um objeto de escambo, em que a família garantia um hímen intacto em troca de alguns pedaços de terra:

[...] na Grécia antiga, garotas que perdiam a virgindade eram vendidas como escravas por arruinar a honra familiar. Na Roma imperial, um pai podia matar a filha e o homem que a seduziu se ela perdesse a virgindade antes do casamento. Até hoje, em alguns países árabes e africanos, mulheres são mutiladas ou apedrejadas por causa de um preconceito que, segundo antropólogos, vem desde a era neolítica, quando os homens começaram a domesticar animais e reprimir suas mulheres. ${ }^{4}$ (grifo nosso).

Séculos após a prática da objetificação da virgindade feminina, no Brasil ainda permaneceu um abominável costume no que se refere ao que seria, supostamente, a primeira noite de uma mulher ou sua primeira

\footnotetext{
${ }^{3}$ O próprio Código Civil de 2002 contemplou expressamente a necessidade de se atender ao critério subjetivo da "moral e dos bons costumes" que cunhou esta expressão em seu artigo 1.638, III, bem como no artigo 2o da Lei no. 5.250/67 dentre outras cartas legais.

${ }^{4}$ SANTOS, Fabiano. Para que serve o hímen? Disponível em: <http://fajacnoticias.blogspot.com.br/2014/11/p ara-que-serve-o-himen.html> Acesso em: 03. nov. 2015.
} 
relação sexual ${ }^{5}$. O pai da então recém-casada apresentava como um troféu, pela manutenção da virgindade até o casamento, o lençol sujo de sangue pelo rompimento do hímen, o que servia de prova da virgindade da filha. ${ }^{6}$

Muito embora a medicina exponha que o hímen pode não ter uma função biológica relevante ${ }^{7}$, essa membrana que é tido como um resquício embrionário sem importância, na verdade, possui uma grande relevância social, patrimonial e, atualmente, adotou a forma de mercantilização, como se fosse um produto comercializável.

De fato, o que ocorreu com o advento da pós-modernidade foi a inversão de valores morais e culturais acerca das relações interpessoais e sexuais de forma a trazer à baila da sociedade uma nova cultura de aceitação da liberdade sexual, principalmente para as mulheres que atualmente podem dizer que possuem maior liberdade para com seu corpo e seu interesse sexual.

Efetivamente, com exceção de raras hipóteses em sociedades moralmente atrasadas em razão de dogmas religiosos, não mais se fala em dotes baseados na virgindade ou em homicídios, punições ou escravização porque a filha mais velha ou mais nova não é mais virgem ou não se casou virgem.

$\mathrm{Na}$ verdade, a valoração da virgindade se adequou à vontade social de acordo com cada época e seus costumes. Em razão do aumento da liberdade sexual e autonomia corporal trazidas pela pós-modernidade, atualmente, a virgindade pode ser mercantilizada ${ }^{8}$, vendida para quem quer pagar o valor que entende ser devido pela conjunção carnal com uma mulher cujo hímen ainda não fora rompido, ou até mesmo utilizar esta característica feminina para a promoção de outros produtos. ${ }^{9}$

Ao se analisar por esta prima, a virgindade sai de um viés patrimonialista em direção à mercantilização, uma vez que esta não é mais utilizada para garantir o aumento da fortuna da família, mas sim para o proveito próprio da mulher que ainda a possui e quer fazer dela uma forma de perceber ganhos econômicos.

Obviamente, a extinção de uma cultura paternalista e patrimonialista que valorava, moral e patrimonialmente, a liberdade sexual das mulheres fez com que o mundo pós-feminismo fosse revolucionado, o que trouxe também consequências reais para a liberdade substancial feminina de poder utilizar seu corpo para finalidades sexuais diversas, a saber como objeto do presente estudo, a gravidez indesejada e o que fazer com ela, tornando-se claramente um problema a ser solucionado pelo legislador e pelo jurista que se deparam com a

\footnotetext{
${ }^{5}$ O Código Civil de 1916 previa em seu artigo 219, IV, até mesmo a anulabilidade do casamento por erro essencial quanto à pessoa, constituindo causa para anular o casamento a "o defloramento da mulher, ignorado pelo marido", ou seja, se a mulher não fosse virgem ao se casar, o marido poderia pedir a anulabilidade do casamento.

${ }^{6}$ SANTOS, Fabiano. Para que serve o hímen? Disponível em: <http://fajacnoticias.blogspot.com.br/2014/11/p ara-que-serve-o-himen.html> Acesso em: 03. nov.2015.

${ }^{7}$ PATRÍCIA, Karlla. Qual a função biológica do hímen? Disponível em: <http:// diariodebiologia.com/2009/10 /qual-a-funcao-biologica-do-himen/> Acesso em: 03. nov. 2015.

${ }^{8}$ ROSA, Guilherme. A venda da virgindade e o livre mercado do pensamento. Disponível em: <http://veja.ab ril.com.br/noticia/ciencia/a-venda-da-virgindade-e-o-livre-mercado-do-pensamento/> Acesso em: 03. nov. 2015.
} 
colisão de princípios ${ }^{10}$ advinda dessa situação, sendo de um lado a vida do feto que está a nascer e de outro a autonomia da mulher de sustentar sua liberdade sexual e poder fazer uso de medicamentos que impedem a gravidez, evitando, às vezes, a nidação ${ }^{11}$ do óvulo já fecundado ou até mesmo procurando métodos abortivos.

Não obstante a verificação do aumento da liberdade sexual, autonomia e autoafirmação feminina no cenário nacional e mundial torna-se importante falar sobre a falibilidade das relações humanas e a liquidez destas que não mais possuem conexões sólidas o suficiente para produzirem efeitos capazes de serem assimilados pelo direito e pelo moralismo social.

Nesse sentido, justificar-se-ia a teoria apresentada por Zygmunt Bauman sobre o homo faber e o homo consumens, que aplicada a uma noção de evolução social expõe que o sexo para o primeiro é carregado de valores morais, praticado com um propósito maior, diferentemente do sexo para o segundo, que vê no ato sexual apenas uma forma de prazer e novidade, sem qualquer carga moral atrelada. ${ }^{12}$

Assim, partindo-se da premissa de que o mundo pós-moderno vive em um estado de constante consumo, o que afeta e influencia diretamente as relações interpessoais, pode-se verificar que os indivíduos passaram a se relacionar da forma como se relacionam com produtos vendidos no mercado, quase baseando-se em uma lei de oferta e procura:

A vida consumista favorece a leveza e a velocidade. E também a novidade e a variedade que elas promovem e facilitam. É a rotatividade, não o volume de compras que mede o sucesso na vida do homo consumens. [...] Qualificar parceiros sexuais tornou-se o primeiro foco de ansiedade. Que tipo de compromissos, se é que algum, a união de corpos impõe? (grifo nosso). ${ }^{13}$

Pode-se inferir com clareza que a sociedade contemporânea passou de homo faber a homo consumens, principalmente nas relações interpessoais, as quais pararam de assumir significados aleatórios vinculados à ideia de que deve haver moralidade ou compromissos em um relacionamento que envolva a união de dois corpos.

As relações permanentes com compromissos a longo prazo que antes poderiam ser pressupostas como algo lógico, concreto e sólido, na pós-modernidade assume o caráter de liquidez, passando a demonstrar que o normal é a rotatividade de pessoas, o que, por óbvio, propaga a ideia de consumo sexual frequente e com diferentes pessoas, em que os parceiros se auto utilizam com o intuito meramente sexual para que tão logo acabe o ato, ambos estejam prontos para partir para uma nova aventura sexual, sem marcas, sem ressentimentos e, principalmente, sem compromissos duradouros.

Com efeito, tudo isso ocorre nos dias de hoje e com bastante constância, caracterizando o que Bauman

\footnotetext{
${ }^{9}$ SANDEL, Michael J. O que o dinheiro não compra: os limites morais do mercado. Rio de Janeiro: Civilização Brasileira, 2012.

${ }^{10}$ DWORKIN, Ronald. Levando os direitos a sério. São Paulo: Martins Fontes, 2002. p. 127/129

${ }^{11}$ Nidação é o processo de implantação do embrião no útero, que ocorre após a fecundação do óvulo, ou seja, após a formação do zigoto.

${ }^{12}$ BAUMAN, Zygmunt. Amor líquido: sobre a fragilidade dos laços humanos. Rio de Janeiro: Zahar, 2004. p. 67.

${ }^{13}$ Ibid. p. 66-68.
} 
chama de "relações de bolso", e, são definidas dessa forma, pois o individuo as guarda no bolso pronto para descarta-las quando quiser, sem qualquer tipo de vínculo permanente ou compromisso constante que seja capaz de estragar a leveza da liquidez das relações interpessoais. Assim, Bauman define que:

Uma relação de bolso bem sucedida, diz Jarvie, é doce e de curta duração. Podemos supor que seja doce porque tem curta duração, e que sua doçura se abrigue precisamente naquela reconfortante consciência de que você não precisa sair do seu caminho nem se desdobrar para mantê-la intacta por um tempo maior. De fato, você não precisa fazer nada para aproveitá-la. Uma 'relação de bolso' é a encarnação da instantaneidade e da disponibilidade. $^{14}$ (grifo nosso).

Desta feita, torna-se possível perceber que a realidade dos relacionamentos interpessoais na pósmodernidade mudou drasticamente. O que antes começava com um espírito de compromisso, atualmente já começa com um final predestinado e esperado por ambos os envolvidos. Isto provoca uma mudança radical nas estruturais sociais uma vez que as relações passaram a ser mais efêmeras e sem significado.

Em termos práticos, a contemporaneidade trouxe a liberdade sexual plena para os indivíduos que não buscam um compromisso ou responsabilidades voltadas à construção da afabilidade geralmente construída a dois. Especificamente no que tange a mulher, esta se atrela cada vez mais à liberdade sexual e autonomia quanto a seu corpo.

De fato, à medida em que se aumenta a variável "liberdade" de um ser, diminui-se a variável "responsabilidade". Nesse aspecto, a promiscuidade social cresce em meio à falibilidade das relações interpessoais, o que quebra diretamente a ideia de outrora que sexo é algo sagrado e deveria ser praticado com finalidades especificamente vinculadas a mandamentos religiosos.

Sociologicamente, o fato de o ser humano estar cada vez mais equiparando suas relações interpessoais a relações comerciais traz a frieza e a constante certeza que efeitos reais tomam lugar na sociedade que insiste em continuar a evolução social baseada na individualidade, disponibilidade e instantaneidade de cada um.

As ferramentas de sociabilidade, reflexo do avanço tecnológico e da vontade dos indivíduos em se relacionarem com maior número de pessoas possíveis no menor nível de intensidade desejável, trazem a possibilidade de que alguém consiga acesso a práticas sexuais de maneira muito mais fácil e rápida do que no passado.

A falibilidade das relações interpessoais, a disponibilidade do ser, a ideia de indivíduo descartável, a rapidez das informações, o consumo voltado às relações sexuais, tudo isso causa efeitos claros como o aumento do uso de drogas como a pílula do dia seguinte (levonorgestrel), pílulas potencialmente abortivas ou efetivamente abortivas e o aumento de abortos e a procura por estes.

A realidade brasileira já demonstra um cenário típico da pós-modernidade, em que vários indivíduos

\footnotetext{
${ }^{14}$ BAUMAN, Zygmunt. Amor líquido: sobre a fragilidade dos laços humanos. Rio de Janeiro: Zahar, 2004. p. 36.
} 
fazem a utilização de drogas, sejam elas contraceptivos normais como a pílula anticoncepcional ou contraceptivos de emergência como o levonorgestrel, conhecido como pílula do dia seguinte, assim como outros fármacos comercializados internacionalmente como o ulipristal, conhecido também como a pílula dos 5 dias. $^{15}$

Feitas as considerações acerca das relações humanas na contemporaneidade, partindo da cultura da estigmatização do sexo à promoção da promiscuidade pós-moderna, objetiva-se, com o presente estudo analisar a relação entre os fármacos mencionados, seus respectivos efeitos e o aborto perante o direito brasileiro e suas teorias sobre a personalidade.

Por meio da dedução como metodologia de abordagem em seus estudos analítico e normativo, este estudo tem como finalidade defender a ideia de que o aborto deve ser descriminalizado, em razão da análise bioética, jurídica e social quanto aos efeitos dos medicamentos Acetato de Ulipristal e Levonorgestrel, tendo como fundamento a ideia de que a teoria mais correta para verificar o início da personalidade é a Teoria da Personalidade Condicionada, sendo relevante se ater à ideia de que, frente à análise de Robert Alexy, o aborto deve ser tratado caso a caso, propondo, portanto, a possibilidade de se proceder à interrupção voluntária da gravidez em determinados casos, o que de fato já acontece com a administração de determinadas drogas, conforme veremos.

\section{A RELAÇÃO ENTRE ABORTO E FEMINISMO: O GENERO NO ABORTO PELO PRISMA BIOÉTICO}

O aborto se revela enquanto uma temática bioética por excelência e que em razão de sua natureza também se relaciona com a problemática referente ao estudo do gênero, uma vez que se vincula às discussões que envolvem o corpo feminino e, principalmente, a liberdade da mulher em contraposição à defesa da vida intrauterina. $^{16}$

De fato, ao se analisar o objeto do presente estudo, o aborto, percebe-se que tal ato se relaciona diretamente com o corpo feminino e com a liberdade da mulher, ambos pontos controversos e mistificados na cultura da heteronormatividade que delimitou, pela teoria dualista, o gênero e o sexo em homem/masculino e mulher/feminino.

A partir dos estudos feministas sobre o gênero e o sexo começou-se a diferenciação entre ambos, expondo que o sexo se relaciona ao órgão genital e reprodutor na anatomia humana, enquanto gênero se trata de uma construção autobiográfica e, principalmente, pessoal e cultural, não existindo uma ligação compulsória entre sexo e gênero.

\footnotetext{
${ }^{15}$ Brazil-Guidelines_2015: Acetato de ulipristal. Disponível em:<http://www.cecinfo.org/customcontent/uploads/2015/05/Brazil-Guidelines_2015.pdf Acesso em 27.ago. 2015.

${ }^{16}$ RAMPIN, Talita T. Dias. Bioética, aborto e processo: desafios de um novo campo de estudo. In MARCHETTO, Patricia Borba et al. Temas fundamentais de direito e bioética. São Paulo: Cultura Acadêmica: Editora UNESP, 2012. p. 163-164.
} 
Ao se falar em gênero e aborto, pretende-se expor com clareza as dominações sociais e imposições culturais voltadas à cada gênero. Especificamente, ao feminino, representado aqui pela mulher, é imposto determinadas condutas e obrigações criadas a partir de um preconceito arraigado aos tempos de outrora, como, i.e., a obrigação moral e cultural da mulher de se tornar mãe. Nesse sentido, poderia ser afirmado o quanto a compulsoriedade moral afeta diretamente a questão do gênero uma vez que obriga-se culturalmente a mulher, atrelada ao gênero feminino, a ser mãe em algum momento da sua vida.

Como contra-argumento sociológico à heteronormatividade que promove a compulsoriedade moral do papel da mulher de se tornar mãe, Simone de Beauvoir afirma notadamente que:

Ninguém nasce mulher: torna-se mulher. Nenhum destino biológico, psíquico, econômico define a forma que a fêmea humana assume no seio da sociedade; é o conjunto da civilização que elabora esse produto intermediário entre o macho e o castrado que qualificam de feminino. ${ }^{17}$ (grifo nosso).

Assim, aponta-se a ideia de que a mulher, assumindo o gênero feminino, não deve ser submetida à moral social que corrompe e deturpa a liberdade substancial feminina que deve prevalecer sobre os engendramentos sociais e culturais da heteronormatividade e dos resquícios de moralidade que ainda sobraram na pósmodernidade.

O significado de ser mulher ou pertencer ao gênero feminino é variável e se intercambia no tempo e no espaço, de modo que a mulher de décadas atrás sofria uma pressão familiar e social muito maior para ser a matriarca de uma família, chegando-se ao absurdo de verificar preconceitos contra as mulheres que decidissem não se casar e ter filhos, seja porque não queria ou porque preferiu se dedicar à sua ascensão profissional.

Dizer que a mulher, seja do presente ou do passado, compõe uma minoria autônoma ou independente é uma inverdade falaciosa contada por uma sociedade que se diz igualitária, mas não efetiva essa igualdade de liberdades entre homens e mulheres, sendo que estas sempre foram social e culturalmente submissas à vontade masculina que ecoava enquanto verdade universal para a sociedade.

Simone de Beauvoir explica que a submissão feminina não se prende ao fator histórico, uma vez que tal fato sempre ocorreu de modo absoluto:

[...] a ação das mulheres nunca passou de uma agitação simbólica; só ganharam o que os homens concordaram em thes conceder; elas nada tomaram; elas receberam. Isto porque não têm os meios concretos de se reunir em uma unidade que se afirmaria em se opondo. Não tem passado, não tem história, nem religião própria [...]. ${ }^{18}$

Evidencia-se claramente que as mulheres compartilham o espaço social com os homens, e em razão de se viver nesse mesmo espaço constroem laços fortes com seus companheiros tidos como supostos opressores, permanecendo as mulheres, como apresenta Beauvoir, em um patamar de inferioridade se comparadas aos

\footnotetext{
${ }^{17}$ BEAUVOIR, Simone de. O segundo sexo. 6. ed. Rio de Janeiro: Nova Fronteira, 1980. p. 9.

${ }^{18}$ BEAUVOIR, Simone de. O segundo sexo. 6. ed. Rio de Janeiro: Nova Fronteira, 1980. p. 13.
} 
homens:

[...] Sim, as mulheres, em seu conjunto, são hoje inferiores aos homens, isto é, sua situação oferece-lhes possibilidades menores: o problema consiste em saber se esse estado de coisas deve perpetuar-se. [...] A humanidade é masculina e o homem define a mulher não em si, mas relativamente a ele; ela não é considerada um ser autônomo [...] Ela não é senão o que o homem decide que seja; daí dizer-se o 'sexo' para dizer que ela se apresenta diante do macho como um ser sexuado: para ele, a fêmea é sexo, logo ela o é absolutamente. A mulher determina-se e diferencia-se em relação ao homem e não este em relação a ela; a fêmea é o inessencial perante o essencial. O homem é Sujeito, o Absoluto; ela é o Outro. ${ }^{19}$

É nessa visão que ao se categorizar o gênero cria-se a classificação de sistemas de diferenças, especificamente, entre homens e mulheres, com a prevalência do falocentrismo frente à qualquer noção de igualdade entre os sexos. Existe, de fato, ainda na pós-modernidade, uma diferença entre homens e mulheres com a superioridade masculina em evidência, o que por si só cria normas culturais e morais para o público feminino que em razão da inferioridade criada, acaba por acolher os mandamentos de uma sociedade tipicamente masculina.

Nesse sentido, a imagem da mulher contemporânea ainda é construída pela cultura falocentrista que vincula o "ser mulher" à ideia da maternidade compulsória. Assim, indagar-se-ia se "ser mulher" é o mesmo que "ser mãe" ou a atuação feminina do "ser mulher" está muito à frente do mero significado de "ser mãe"?

Aparentemente, mesmo vivendo sobre o pálio da pós-modernidade, a sociedade impõe papéis aos seus atores sociais que precisam atuar em conformidade com cada papel designado pelo falocentrismo. Desta feita, ainda que a evolução seja constante e o mundo se encontre em um patamar de tolerância e adequabilidade dos indivíduos às suas respectivas existências e significâncias, a mulher ainda sofre de estigmas insolúveis capazes de trazer obrigações morais desnecessárias como o suposto dever de se tornar mãe ou a constante obrigação de jamais abortar, seja porque a religião aplica seu dogma e sacraliza a moral da benevolência da vida de um feto em detrimento da liberdade e autonomia sobre o corpo ou porque a sociedade espera de uma mulher que esta não pratique a interrupção da gravidez. Nesse contexto, explicita-se que:

Ser mulher implica em assumir o papel de mulher em determinado contexto. E o que define o conteúdo e limites desta existência? O contexto no qual ela está inserida. Em uma sociedade falocêntrica, na qual a ideia de sujeito está centrada no homem, a existência da mulher é adjetivada como secundária, constituindo mesmo objeto em relação àquele sujeito. Qualquer atuação dela para além do papel de mulher que lhe fora impigido é entendido como deturpação de performance e deslegitima a continuidade da interpretação do papel. $\underline{\text { Se }}$ à mulher é atribuído o papel de genitora, espera-se que ela atue como mãe sempre que esta interpretação for invocada. Qualquer desvirtuamento desta atuação originária (como, por exemplo, na hipótese da mulher refutar a maternidade e pretender o aborto) acarreta sua descaracterização no contexto maior da encenação (vida em sociedade). Sempre coadjuvante, nunca protagonista de sua própria existência. ${ }^{20}$ (grifo nosso).

\footnotetext{
${ }^{19}$ Ibid.p. 18.

${ }^{20}$ RAMPIN, Talita T. Dias. Bioética, aborto e processo: desafios de um novo campo de estudo. In MARCHETTO, Patricia Borba et al. Temas fundamentais de direito e bioética. São Paulo: Cultura Acadêmica: Editora UNESP, 2012. p. 167.
} 
De fato, a mulher contemporânea permanece escrava de si mesmo e da sociedade que impõe determinados comportamentos e condicionamentos morais e culturais. Abortar não é um direito da mulher que possui seu corpo e quer a ele aplicar, logicamente, suas regras, mas desde os tempos sociais mais remotos, o aborto tem sido visto enquanto um crime que ceifa a vida de uma "pessoa" que está a nascer.

Por regra de conduta imposta socialmente e pelo ordenamento jurídico pátrio, a mulher é proibida de abortar de maneira sui generis, sendo possível a prática do aborto apenas em dois casos contemplados no direito penal brasileiro e um caso julgado pelo Supremo Tribunal Federal em 2005. ${ }^{21}$

O Direito Penal, regulador de questões atreladas aos bens jurídicos maiores, promove um tratamento sexista no que se refere à liberdade de abortar quando tipifica o aborto como crime. Denota-se, pela simples análise ao ordenamento jurídico brasileiro em sua esfera penal, o controle abusivo do Estado no que tange à liberdade feminina ou ainda sobre a autonomia da mulher perante seu corpo.

A maneira como o aborto é tratado pela ciência penal nos artigos 124, 125 e 126, todos do Código Penal Brasileiro, apresenta apenas uma posição degradantemente sexista e uma ausência de técnica legislativa para poder dar os contornos necessários ao ato de interromper a gravidez voluntariamente.

Pela ciência dos artigos supracitados, não é possível saber exatamente o alcance que a teleologia dessas normas abertas e irrestritas atinge. Nesse sentido, por uma simples análise, poder-se-ia dizer que o direito penal pune tanto a gestante que está grávida a 5 dias ou a 30 semanas, não existindo no direito brasileiro uma regra balizadora entre os interesses conflitantes da sociedade pró-possibilidade de vida e da mulher e sua liberdade e autonomia.

Não obstante, pela mesma ideia da Carta Penal, um dos fármacos vendidos no Brasil como contraceptivo de emergência possui um efeito que poderia causar o aborto ${ }^{22}$, dependendo da teoria do início da personalidade adotada pelo ordenamento jurídico brasileiro. E, se assim o fosse, a mulher que fizesse uso do contraceptivo de emergência poderia, caso o sistema jurídico brasileiro adotasse a teoria concepcionista, estar a praticar o crime previsto no artigo 124 do Código Penal Brasileiro.

Torna-se fácil perceber a ausência de plausibilidade no Código Penal ao regular de forma generalista a questão, seja por incompetência legislativa ou sexismo patriarcal:

[...] O corpo feminino é o objeto de tutela do direito penal na medida do interesse de seu sujeito possuidor: o homem, sujeito de direito por excelência. Neste sentido, importante notar que, na América Latina, homem e mulher ocupam lugares distintos no ordenamento jurídico e na tutela estatal. É latente a subjugação da mulher ao homem em uma estrutura patriarcal, pois esta sublima sua autonomia e dissipa o fato de que ela é um fim em si mesmo. No patriarcado, a mulher é um meio (objeto) para alcançar determinado fim (reprodução

\footnotetext{
${ }^{21}$ Respectivamente o artigo 128, I e II do Código Penal Brasileiro e a ADPF no. 54 de 27 de abril de 2005.

${ }^{22}$ Um dos efeitos do levonorgestrel, também conhecido como pílula do dia seguinte, é impedir que o óvulo fecundado se aloje no útero, o que, para a teoria concepcionista, já seria considerado como um aborto, pelo fato de o óvulo já ter sido fecundado.
} 
humana, prazer sexual, manutenção da família e da esfera privada, educação dos filhos), que é estabelecido pelo sujeito (homem) conforme sua vontade (moral). ${ }^{23}$

Com efeito, sabe-se que a mulher é realmente subjugada às vontades estatais que traduzem a moral da sociedade que é, em sua maioria, sexista ou religiosa, e que vê a mulher como um objeto criado para estar à disposição do homem e suas idiossincrasias flutuantes que impedem o florescer da autonomia feminina e liberdade quanto ao seu corpo.

Curiosamente, o Código Penal Brasileiro em seu artigo 128, II, traz a figura de permissibilidade do aborto no caso de risco de morte para a gestante ou em caso de gravidez resultante de estupro. A primeira hipótese, plausivelmente, o legislador deu prevalência à vida da pessoa já nascida, a gestante, em detrimento da vida do feto gestado, por tratar-se de uma questão óbvia em garantir a vida de um ser já existente. Na segunda hipótese, aborto em razão do estupro, o legislador também agiu com plausibilidade e acertadamente ao garantir a liberdade da mulher em poder escolher não gestar uma vida com a qual não consentiu criar.

Nessa mesma lógica, indaga-se: qual o valor objetivo da vida de um feto desejado e outro indesejado (em razão do estupro)? Qual a diferença entre não consentir com a gravidez resultante de estupro e o não consentimento da gravidez resultante de falha no método contraceptivo? A gravidez seria uma consequência sempre esperada do ato sexual cujos parceiros deveriam arcar com esta em toda e qualquer hipótese? Por que o ordenamento jurídico brasileiro aceita o aborto resultante de estupro, mas não aceita o aborto em caso de falha de método contraceptivo ou até mesmo em razão da não utilização de um método?

Se houver um raciocínio ascético e isento de axiologias teológicas e amorais, encontrar-se-á a resposta de que o aborto realizado em estágios iniciais da gravidez, i.e., até a décima segunda semana de gestação, não seria necessariamente uma afronta à vida intrauterina, até mesmo porque esta ainda não existiria, salvo se o indivíduo que se encontra em uma situação como a mencionada for adepto da teoria concepcionista, acreditando que a vida tem início a partir da fecundação do óvulo pelo espermatozoide. Entretanto, ressalta-se que para este indivíduo, uma simples pílula do dia seguinte poderia ser um método abortivo.

Opera-se que as respostas para as perguntas apresentadas deveriam abster-se de axiologias e idiossincrasias voltadas à religião ou à moral, ambas arraigadas no patriarcalismo sexista de outrora. Assim, o ordenamento jurídico brasileiro valora, objetivamente, de forma inferior a vida intrauterina resultante de estupro apenas porque se trata de uma gravidez resultante de um ato condenável moral e juridicamente. Entretanto, em uma análise puramente objetiva e ascética, a vida intrauterina de um feto desejado e a de um resultante de estupro, possuem exatamente o mesmo valor. Contudo não se busca aqui defender a compulsoriedade da gravidez decorrente de estupro, mas apenas demonstrar as incongruências jurídicas em razão de uma moral axiológica

\footnotetext{
${ }^{23}$ RAMPIN, Talita T. Dias. Bioética, aborto e processo: desafios de um novo campo de estudo. In MARCHETTO, Patricia Borba et al. Temas fundamentais de direito e bioética. São Paulo: Cultura Acadêmica: Editora UNESP, 2012. p. 168.
} 
construída juridicamente.

Sabe-se assim que o ordenamento jurídico brasileiro não aceita o aborto em caso de falha de método contraceptivo ou ausência do uso deste em razão de uma moral sexista ou de uma moral religiosa que obsta a autonomia da mulher em escolher quando, efetivamente, vai se engravidar.

Obviamente, não se busca nem se defende no presente estudo a utilização do aborto como um contraceptivo de emergência, mas sim uma análise que demonstre a plausibilidade em se permitir o aborto em caso de gravidez indesejada, independentemente do motivo, desde que regulado e estipulado metodologicamente um prazo para a interrupção da gravidez.

Não se preza aqui a banalização da vida intrauterina nem se pugna pela possibilidade da legalização do aborto de uma gestante com 30 meses de gestação. Entretanto, critica-se a postura da norma penal brasileira que generaliza o aborto e não o permite em caso de falha de método contraceptivo ou ausência deste.

Nesse sentido, percebe-se que a objetividade da norma penal se dá contrária à liberdade sexual e à autonomia corporal da mulher ao invés de propor uma objetividade temporal no que se refere ao tempo de gestação, permitindo o aborto, como o fazem a maioria dos países europeus, dentro de uma vacância tolerável.

Se tal proposta fosse aceita, acabaria o problema em saber se a gravidez foi ou não resultante de estupro ou em razão de falha de método contraceptivo ou ausência dele, ou seja, a praticidade legal e a proteção fundamental aos direitos da mulher seriam atendidas de maneira plena pelo ordenamento jurídico brasileiro.

De igual maneira, o ordenamento jurídico brasileiro não pensou na previsão da possibilidade do aborto por questões econômicas ou sequer cogitou a hipótese do dano de se ter um filho, que acontece quando a mulher se vê obrigada a deixar de seguir seus caminhos profissionais e suas escolhas em razão de uma gravidez não consentida advinda de um ato sexual consentido, porém penalizado pela sociedade, pelo direito e pela religião.

De fato, percebe-se que a não descriminalização do aborto possui um viés de vingança contra a mulher que consente no ato sexual, mas não quer nem espera engravidar, uma vez que a lei brasileira aceita o aborto de gravidez resultante de estupro, mas não aceita o aborto resultante de gravidez por falha ou ausência de utilização de método contraceptivo.

Sociologicamente, é como se a lei penal e o ordenamento jurídico brasileiro como um todo expusessem a máxima "a gravidez não desejada, que é diferente da não consentida, é a penalização pelo ato de copular", ou seja, o ato sexual poderá possui uma punibilidade intrínseca aplicável irremediavelmente à mulher que não deseja uma gravidez.

A realidade normativa brasileira é triste e desrespeitosa para com os direitos da mulher e sua autonomia, constituindo o corpo feminino um espaço público de discussões a respeito de qualquer questão que não inclua a opinião da maior interessada, a mulher. 
Talita T. D. Rampin, afirma que:

[...] tem-se que a mulher é considerada um meio para a persecução de finalidade especificas. Importa ao presente estudo a expectativa alimentada pela sociedade do desempenho de seu papel romantizado de geratriz. Recorrento ao simbolismo judaico-cristão, disseminado e arraigado nos países ocidentais, espera-se que a mulher desempenhe o papel mãe imaculada, fecundada por um espírito santo e, portanto, sem desfrutar de prazeres mundanos. Espera-se que a mulher vivencie a gravidez em sua plenitude, a despeito de sua vontade e dignidade, pois o fruto que carrega em seu ventre torna-se um verdadeiro interesse público, contra o qual a geratriz não pode atentar, sob pena de ser repelida pelos demais membros da sociedade, que a repugnarão na medida em que se afastar do papel de mãe, inclusive, não importando se referida maternidade representar uma verdadeira via crusis. $^{24}$

Certo é que a sociedade se baseia em estigmas teológicos para repudiar qualquer meio de cientificidade socialmente reluzente que poderia de alguma forma servir como meio de maximizar a dignidade humana, seja pela proteção correta da vida intrauterina baseada em prazos objetivos ou pelo suporte ao direito fundamental de liberdade e autonomia da mulher.

\section{O Projeto de Lei ${ }^{\circ}$. 5069/2013 e a gravidez compulsória: um atentado contra as mulheres}

O legislativo brasileiro, por meio da Câmara dos Deputados, aprovou, na Comissão de Constituição e Justiça, o Projeto de Lei no. 5069/2013, que possui o objetivo de acrescentar o artigo 127-A ao Decreto-Lei no 2.848/40, ou seja, o Código Penal Brasileiro criando indevidamente mais uma figura penal contra a liberdade feminina. ${ }^{25}$

A proposta é tipificar como crime contra a vida o anúncio de meio abortivo, prevendo ainda penas específicas para quem induz a gestante à prática de aborto. Dessa feita, em termos gerais, qualquer tipo de fármaco como o Levonorgestrel ou o Ulipristal que possuem efeitos abortivos teriam que ser proibidos, pois sua indicação médica poderia ser enquadrada no suposto crime previsto no PL no. 5069/2013 assim como suas respectivas comercializações teriam que ser suspensas.

Em linhas gerais, e por consequência lógica, os medicamentos administrados às mulheres vítimas do crime de estupro não mais poderiam ser utilizados sob pena de o próprio SUS, que oferece o coquetel pósestupro, incorrer na proposta de crime consubstanciada no Projeto de Lei mencionado.

De fato, o que o legislativo está a propor com tal medida é a desvalorização da autonomia, dignidade e liberdade feminina a todo custo sob o argumento axiológico e indiretamente religioso de proteção à vida intrauterina a qualquer preço. Chega-se ao absurdo de impor, indiretamente, à mulher vítima de estupro, a gravidez e manter em seu corpo o fruto de um crime. Tudo isso, ressalta-se, por mera moralidade e crenças

\footnotetext{
${ }^{24}$ RAMPIN, Talita T. Dias. Bioética, aborto e processo: desafios de um novo campo de estudo. In MARCHETTO, Patricia Borba et al. Temas fundamentais de direito e bioética. São Paulo: Cultura Acadêmica: Editora UNESP, 2012. p. 169.
} 
instituídas em um país que se intitula "laico". ${ }^{26}$

Com essa proposta, o Código Penal Brasileiro teria que readequar seus artigos e para manter uma plausibilidade legal, deveria extirpar a permissibilidade do aborto em caso de estupro previsto em seu artigo 128, II, uma vez que os médicos estariam proibidos de induzir a gestante ou até mesmo praticar o aborto sob pena de incorrerem na figura a ser criada, o artigo 127-A.

Não obstante, importante é a crítica feita por Soraya Lunardi que observa que "o direito é masculino" 27. Leciona a autora que o aborto no Brasil é questão de saúde pública, uma vez que a ilegalidade da interrupção voluntária da gravidez abriu portas para o mercado paralelo que oferece atualmente a possibilidade de gestantes abortarem em silêncio a gravidez indesejada. De fato, o que o Estado faz é se calar perante um problema de saúde pública e agora promover o enrijecimento da legislação penal, que deveria ser utilizada em ultima ratio:

O direito das mulheres a decidir sobre a gestação e a receber ajuda médica qualificada é garantido em praticamente todos os países com alto índice de desenvolvimento humano. Dito de outra maneira, o progresso social e econômico e a liberdade religiosa são, hoje, sinônimos de garantia da liberdade das mulheres a determinar sua vida pessoal e familiar. ${ }^{28}$

A saber, a maioria dos países integrantes da União Europeia já aceitam a prática do aborto, alguns com utilização de critérios biológicos e científicos e outros ainda aplicam a possibilidade da interrupção voluntária da gravidez com base em critérios econômicos, como é o caso da Inglaterra. ${ }^{29}$

Por óbvio, muito embora o Brasil se intitule um país laico, grande parte de suas manifestações legislativas possui um fundo religioso e mediocremente moralista, de forma a retirar direitos dos indivíduos, principalmente, nesse caso, das mulheres, um direito inato, a liberdade de possuir o próprio corpo, com a desculpa em forma de prospecção desmedida ou dogma teológico como forma de crença emblemática de que se retira uma vida a abortar.

\section{OS CONTRACEPTIVOS DE EMERGENCIA: LEVONORGESTREL E ULIPRISTAL, PROTEÇÃO À LIBERDADE DA MULHER OU MÉTODOS ABORTIVOS?}

Com o desenvolvimento científico na pós-modernidade em que as relações entre as pessoas se tornaram

\footnotetext{
25 CÂMARA DOS DEPUTADOS. Projeto de Lei no. 5069/2013. Disponível em: <http://www2.camara.leg.br/p roposicoesWeb/fichadetramitacao?idProposicao=565882> Acesso em: 08. nov. 2015.

${ }^{26}$ Curioso é notar que um dos deputados que propuseram o Projeto de Lei no. 5069/2013 é padre. Padre Ton - PT/RO, além do Deputado Eduardo Cunha (PMDB/RJ) e outros dez deputados. Disponível em: <http://www2.camara.leg.br/proposicoesWeb/prop_autores;jsessionid=BD12F7109C7 8DB490B22B42F6639E58A.proposicoesWebl?idProposicao=565882> Acesso em: $10 . \quad$ nov. 2015. http://www2.camara.leg.br/proposicoesWeb/fichadetramitacao?idProposicao=565882

27 LUNARDI, Soraya R. G. O direito é masculino. Estadão Noite. em. 17.11.2015. Disponível em: http://www.unesp.br/portal?hc_location=ufi\#!/noticia/20033/o-direito-e-masculino/Acesso em: 10. dez. 2015.

${ }^{28}$ LUNARDI, Soraya R. G. O direito é masculino. Estadão. p. 17.11.2015.

${ }^{29}$ Bioethcis and law observatory. Document on voluntary interruption of pregnancy. Barcelona, april 2008. Disponível em <http://www.ub.edu/fildt/revista/pdf/RByD14_Interrupcion.pdf>. Acesso em 02 jan 2015.
} 
mais fluídas, demonstrou-se válida a iniciativa farmacológica que proporciona à mulher contemporânea a possibilidade de poder controlar o momento de sua vida em que se tornará gestante, e, consequentemente, mãe, ou seja, deixou ao arbítrio não apenas do homem, o planejamento familiar.

Com a criação dos fármacos Levonorgestrel, conhecido como "pílula do dia seguinte", e Acetato de Ulipristal, conhecido, no Brasil, como "pílula dos 5 dias" ou na Europa como "ellaOne", caso a mulher queira consumir tais drogas para evitar a gravidez, se esta não fizer uso de outro contraceptivo como as pílulas anticoncepcionais $^{30}$, DIU ou diafragma, basta apenas se dirigir à farmácia mais próxima e comprar, sem a necessidade de receituário médico.

O Levonorgestrel cuja fórmula química é $\mathrm{C}_{21} \mathrm{H}_{28} \mathrm{O}_{2}$, também nomeado L-norgestrel ou D-norgestrel e conhecido popularmente como "pílula do dia seguinte", trata-se de um método contraceptivo de emergência, utilizado para se evitar a gravidez indesejada, seja ela em decorrência de fallha ou não utilização de outro contraceptivo ou em caso de estupro. Trata-se de um contraceptivo hormonal de segunda geração, sendo, de fato, um tipo de progesterona sintética, diferenciando-se dos contraceptivos regulares por agir diferente no corpo feminino enquanto inibidor da gravidez. ${ }^{31}$

Como contraceptivo regular, o Levonorgestrel muitas vezes é associado ao Etinilestradiol, contendo a seguinte posologia: Levonorgestrel $(0,15 \mathrm{mg})$ e Etinilestradiol para a formação do contraceptivo regular de administração diária ${ }^{32}$, como a pílula anticoncepcional cujo efeito é inibir a ovulação. Nesse sentido, pode-se dizer que o Levonorgestrel também é utilizado como contraceptivo regular, muito embora em quantidade menor e diária associado a outro elemento, sendo que dessa forma não constituiria um fármaco potencialmente abortivo, mas meramente inibidor de ovulação.

Entretanto, além de ser usado em contraceptivos normais, o Levonorgestrel também pode ser utilizado como contraceptivo de emergência, quando é administrado em doses maiores se comparado à contracepção regular. Sua posologia enquanto medicamento potencialmente abortivo é formada pelo uso de 1,5 mg de Levonorgestrel que pode ser dividida em duas doses de $0,75 \mathrm{mg}$ cada, sendo uma dose até 72 horas após o ato sexual e outra dose após 12 horas da administração da primeira pílula.

Caso a mulher prefira, no entanto, tomar apenas uma pílula, com administração em única dose, o mais rápido possível após o fato, em um limite de até 72 horas, é possível encontrar o Levonorgestrel uno, concentrado em 1,5 mg, cujos os efeitos são: a) a inibição da ovulação; b) o impedimento da fertilização do óvulo pelo esperma e c) caso tenha ocorrido a fecundação, o medicamento impede que o óvulo fecundado se aloje no útero, levando-

\footnotetext{
${ }^{30}$ Todavia, ressalta-se que o Ulipristal ainda não é comercializado no Brasil.

${ }^{31}$ Brazil-Guidelines_2015: Levonorgestrel. Disponível em:<http://www.cecinfo.org/custom-content/uploads/2015/05/BrazilGuidelines_2015.pdf Acesso em 27.ago. 2015

${ }^{32}$ BulasMed: Levonorgestrel. Disponivel em:<http://www.bulas.med.br/p/levonorgestrel. Acesso em 27. ago. 2015
} 
se em consideração que a administração do Levonorgestrel nas quantidades mencionadas não são recomendadas para utilização diária. ${ }^{33}$

Muito embora um de os efeitos mencionados do Levonorgestrel possa ser qualificado como abortivo, o Ministério da Saúde, por meio de um manual explicou que:

Não existe nenhuma sustentação cientifica para afirmar que a AE seja método que resulte em aborto, nem mesmo em percentual pequeno de casos. As pesquisas asseguram que os mecanismos de aça ${ }^{\circ}$ da $\mathrm{AE}$ evitam ou retardam a ovulaça o, ou impedem a migraça o dos espermatozoides. Não ha\ encontro entre os gametas masculino e feminino e, portanto, não ocorre a fecundação. A diminuição progressiva da efetividade da $\mathrm{AE}$, conforme transcorre o tempo a partir da relação sexual, e a incapacidade de produzir sangramento imediato ou em caso de gravidez são demonstrações simples, mas evidentes, de que a $\mathrm{AE}$ e区 $\mathrm{\bigotimes}$ capaz de evitar a gravidez, nunca de interrompe ${ }^{\wedge}$-la. A AE impede a fecundação e não ha $\$ indicadores de que ela atue após esse evento. Este fato deveria ser suficiente para estabelecer, claramente, a ausência de efeito abortivo. ${ }^{34}$ (grifou-se)

Dessa forma, pela pesquisa promovida pelo órgão governamental, o Levonorgestrel não seria um método abortivo, ainda que se levasse em conta a teoria concepcionista que promove a ideia de que a vida começa na concepção, diferenciando-se da teoria natalista e da personalidade condicionada, uma vez que cientificamente verificou-se que não existem indicadores seguros que comprovem a atuação do Levonorgestrel após a fecundação.

Muito embora o estudo científico tenha revelado a não ocorrência de aborto em caso de utilização do Levonorgestrel, algumas entidades pró-vida se manifestam contrárias à permissibilidade do uso do fármaco mencionado, pois consideram-no abortivo, chamando-o de "aborto do dia seguinte", sendo afirmado pelo Pe. Luiz Carlos Lodi da Cruz presidente do Pró-Vida de Anápolis:

\begin{abstract}
A que estou-me referindo? À chamada "pílula do dia seguinte", ou seja, "um preparado a base de hormônios (pode conter estrogênio, estrogênio/progestogênio ou somente progestogênio) que, dentro de, e não mais do que 72 horas após um ato sexual presumivelmente fértil, tem uma função predominantemente 'anti-implantação', isto é, impede que um possível ovo fertilizado (que é um embrião humano), agora no estágio de blástula de seu desenvolvimento (cinco a seis dias depois da fertilização) seja implantado na parede uterina por um processo de alteração da própria parede. O resultado final será assim a expulsão e a perda desse embrião". [...] Não só o aborto é crime, mas o mero anúncio de 'processo, substância ou objeto destinado a provocar aborto' constitui contravenção penal (art. 20 da Lei das Contravenções Penais). O Ministério da Saúde, que liberou o uso e a comercialização de tal abortivo, pode e deve ser processado pelo Ministério Público. Convém que o quanto antes entremos com uma representação solicitando a apuração dos fatos e a punição dos responsáveis. A liberação do comércio dos "contraceptivos de emergência" (cujo uso também está previsto na Norma Técnica do Aborto) é mais um dos tristes episódios da administração do Ministro José Serra. ${ }^{35}$
\end{abstract}

\footnotetext{
${ }^{33}$ Brazil-Guidelines_2015: Levonorgestrel. Disponível em:<http://www.cecinfo.org/custom-content/uploads/2015/05/BrazilGuidelines_2015.pdf Acesso em 27.ago.2015

${ }^{34}$ MINISTÉRIO DA SAUUDE. Anticoncepçã o de Emerge^ncia: perguntas e respostas para profissionais de saúde/Ministério da Saúde, Secretaria de Atenção a冈 Sau囚de. Brasília: Ministério da Saúde, 2005. p. 13. Disponível em: <http://bvsms.saude.gov.br/bvs/publicacoes/caderno3_saude_mulher.pdf> Acesso em: 19. nov. 2015. Explica-se que a sigla AE significa Anticoncepção de Emergência.

${ }^{35}$ CRUZ, Luis Carlos L. da. O aborto do dia seguinte. Disponível em: <http://www.providaanapolis.org.br/inde
} 
Inobstante às colocações científicas e outras de cunho axiologicamente pessoal, afirma-se que a pílula do dia seguinte atua também de forma a alterar o ciclo menstrual, antecipando o momento da menstruação, sendo comum ocorrer sangramentos após um prazo de 2 até 5 dias após a utilização.

Para a OMS - Organização Mundial da Saúde o Levonorgestrel não é considerado método abortivo, uma vez que uma medicação abortiva seria aquela que age após o óvulo fecundado já ter sido implantado no útero, e ainda que todos os efeitos do fármaco mencionado possa ocorrer em uma mulher, isto não o tornaria um método abortivo. ${ }^{36}$

De fato, defende-se no presente estudo que o aborto é a perda de um embrião que estava se desenvolvendo já implantado na parede do útero, sendo que a ação do Levonorgestrel é anterior à implantação do óvulo fecundado àquele órgão, não sendo, portanto, uma droga que provoca aborto, pois considera-se aqui que a inviabilidade do óvulo fecundado pela impossibilidade de instauração e manutenção daquele na parede do útero, como um dos efeitos do Levonorgestrel, não se trata de aborto.

Inobstante a existência do fármaco Levonorgestrel, fora do Brasil, mais especificamente na Europa, também é comercializado o Acetato de ulipristal, conhecido como HRP 2000 e como "pílula dos 5 dias", tratando-se de um modulador seletivo dos receptores da progesterona (SPRM), desenvolvido para ser utilizado como contraceptivo de emergência por mulheres, assim como o Levonorgestrel. ${ }^{37}$

O Acetato de ulipristal pode ser administrado em até 120 horas, ou seja, 5 dias após as relações sexuais sem proteção, ausência ou falha do método contraceptivo utilizado, sendo que em comparação ao Levonorgestrel, por um estudo oficializado na revista científica Lancet, tal indica que o Acetato de Ulipristal se mostra mais eficiente que o Levonorgestrel. ${ }^{38}$

O fármaco mencionado foi efetivamente aprovado pela Agência Europeia de Medicamentos em 2009, sendo comercializado em caixa com 1 comprimido de $30 \mathrm{mg}$ que deve ser usado em dose única. Observa-se que este medicamento é considerado como potencialmente prejudicial ao embrião, e seu nome comercial è "EllaOne".

Diferentemente do que é falado a respeito do Levonorgestrel, o Acetato de Ulipristal possui efetivamente outros efeitos além dos efeitos do Levonorgestrel:

Ulipristal also increases the thickness of the natural mucus at the neck of the womb (cervix), making it more difficult for sperm to cross from the vagina into the womb. By preventing

x.php/todos-os-artigos/item/343-o-aborto-do-dia-seguinte> Acesso em 19. nov. 2015.

36 "Levonorgestrel-alone emergency contraception pills are very safe and do not cause abortion or harm future fertility. Side-effects are uncommon and generally mild." In WORLD HEALTH ORGANIZATION.Emergency contraception. Disponível em: <http://www.who.int/me diacentre/factsheets/fs244/en/> Acesso em: 19. nov. 2015. Tradução do autor: "Pílulas de contracepção de emergência de Levonorgestrel, utilizadas sem administração conjunta de outra droga, são muito seguras e não causam aborto ou prejudicam a fertilidade futura. Os efeitos colaterais são raros e geralmente ligeiros".

${ }^{37}$ Brazil-Guidelines_2015: Acetato de ulipristal. Disponível em:<http://www.cecinfo.org/customcontent/uploads/2015/05/Brazil-Guidelines_2015.pdf Acesso em 27.ago. 2015.

${ }^{38}$ CYCLOPAEDIA. Ulipristal. Disponível em: <http://pt.cyclopaedia.net/wiki/Ulipristal> Acesso em: 19. nov. 2015. 
sperm entering the womb, successful fertilisation of any egg that is there is less likely. Ulipristal is also thought to alter the lining of the womb, preventing it from being prepared for a fertilised egg. This means that if an egg is released from the ovaries and is fertilised, it cannot implant into the womb and therefore pregnancy is avoided. ${ }^{39}$

Desta feita, se havia dúvidas acerca do Levonorgestrel ser ou não abortivo, quanto ao Acetato de Ulipristal, já permanece a certeza de que para os adeptos à teoria concepcionista, este fármaco é potencialmente uma afronta à vida intrauterina, pois impede, efetivamente, que o óvulo fecundado seja instaurado na parece do útero.

Entretanto, expõe-se aqui que para o presente estudo, o qual considera a liberdade da mulher, autonomia e dignidade direitos a serem protegidos e resguardados pelo Estado, pugnando pela liberação do aborto, ambos os fármacos não seriam abortivos, pois não se considera aqui que a vida começa, efetivamente, a partir da concepção.

Ademais, ainda que tais medicamentos fossem, de fato, abortivos para os adeptos da teoria concepcionista, ou seja, tivessem o efeito de expulsar um óvulo já fecundado e transformado em feto no primeiro ou segundo mês de gestação, o presente estudo reforça a ideia de que o princípio da liberdade e autonomia da mulher deve prevalecer sobre a ideia de possibilidade de vida de um feto ainda em formação, sem viabilidade de vida extrauterina.

\section{ANÁLISE DOS EFEITOS DO LEVONORGESTREL E ACETATO DE ULIPRISTAL PELAS TEORIAS: NATALISTA, CONCEPCIONISTA E DA PERSONALIDADE CONDICIONADA}

O direito brasileiro em seu artigo $2^{\circ}$ do Código Civil expõe que a personalidade civil da pessoa começa com o nascimento com vida, colocando a lei, desde a concepção, a salvo os direitos do nascituro. Ocorre que, seja por falta de técnica legislativa ou teleologia normativa, o artigo mencionado não deixou claro qual teoria seria adotada pelo ordenamento jurídico brasileiro, se a Natalista, a Concepcionista ou a da Personalidade Condicionada. Antes mesmo de adentrar à interdisciplinaridade entre bioética e direito civil, passa-se a expor o que representa cada uma dessas teorias.

A Teoria Natalista admite o nascimento com vida como condição para a aquisição da personalidade, entendida como aptidão genérica para aquisição de direitos e deveres, ou seja, defende, efetivamente, o nascimento com vida como fator condicionante para a personalidade civil, desprezando a concepção. A máxima

\footnotetext{
39 NETDOCTOR. EllaOne: ulipristal acetate. Disponível em: <http://www.netdoctor.co.uk/medicines/sexualhea lth/a8735/ellaone-ulipristal-acetate/> Acesso em 19. nov. 2015. Tradução do autor: "Ulipristal também aumenta a espessura do muco natural, no colo do útero (colo do útero), tornando-a mais difícil para o esperma de atravessar da vagina para o útero. Ao impedir o esperma de adentrar ao útero, a fertilização bem sucedida de qualquer óvulo é menos provável. Ulipristal também é pensado para alterar o revestimento do útero, impedindo-o de ser preparado para um óvulo fertilizado. Isto significa que, se um óvulo é liberado dos ovários e é fertilizado, ele não pode ser implantado no útero e por conseguinte a gravidez é evitada”.
} 
adotada por esta teoria é a de que "a personalidade civil começa com o nascimento com vida". ${ }^{40}$

A Teoria Concepcionista afirma existir os direitos do embrião, ou seja, a partir do momento do encontro dos gametas masculino e feminino, isto é, daquele que se encontra em vida intrauterina, defendendo a ideia de personalidade civil desde a concepção. Logo, todo e qualquer embrião implicaria em vida. Assim, por essa teoria, $\mathrm{o}$ direito afirmaria que "a personalidade começa da concepção e não do nascimento com vida" ${ }^{\text {", }}$ muito embora personalidade e vida são conceitos distintos.

Como desmembramento da teoria natalista e concepcionista, como se existisse uma mescla entre ambas, a Teoria da Personalidade Condicionada afirma que o embrião é pessoa condicional, sendo esse condicionamento vinculado ao nascimento com vida ${ }^{42}$, ou seja, os direitos do nascituro são reconhecidos como válidos e existentes, mesmo enquanto apenas um feto, mas para serem efetivados dependeriam do nascimento com vida daquele feto, que receberia a personalidade completa ao nascer.

Após uma noção a respeito das teorias da personalidade, torna-se importante refletir sobre os efeitos do Levonorgestrel e do Acetato de Ulipristal dentro de cada teoria apresentada, expondo ainda a validade jurídica e a possibilidade de existência e permanência no ordenamento jurídico de cada fármaco.

Considerando que a vida seja o fator primordial para se atribuir a personalidade a alguém, especificamente a uma pessoa física, cujo nascimento não depende de registro na junta comercial, infere-se, assim, a análise de que os efeitos dos fármacos mencionados teriam influências sobre a vida do nascituro, e, por consequência, afetaria a personalidade do embrião, uma vez que se não há vida, não há de se falar em personalidade. Desta feita, para uma análise às teorias mencionadas, equiparar-se-á vida à personalidade.

Nesse sentido, pela teoria natalista, os efeitos, seja o fármaco Levonorgestrel ou Acetato de Ulipristal, não seriam abortivos ou ilícitos, uma vez que a personalidade é atribuída ao nascituro quando há nascimento com vida. Ressalta-se que essa teoria não especifica quando ocorre o início da vida, entretanto, ao atribuir personalidade apenas ao nascituro que nasce com vida, ela despreza a personalidade do embrião ainda em estado intrauterino, o que, por consequência, viabilizaria a utilização dos fármacos independentemente de qualquer efeito existente sobre o feto, uma vez que este não possui personalidade.

Já no que se refere à teoria concepcionista, um dos efeitos da pílula do dia seguinte, nesse caso o Levonorgestrel seria abortivo, ou seja, quando esta impede que o óvulo já fecundado se instaure no útero, pois a personalidade aqui é considerada existente desde a concepção. Assim, o Levonorgestrel nem sequer poderia ser comercializado, por ser potencialmente abortivo considerando a teoria concepcionista.

\footnotetext{
${ }^{40}$ CHINELLATO, Silmara J. de Abreu. Estatuto jurídico do nascituro: a evolução do direito brasileiro. Coimbra: Almedina, 2009. p. 428-429. In CAMPOS, Diogo Leite de; CHINELLATO, Silmara J. de Abreu. Pessoa humana e direito. Coimbra: Almedina, 2009.

${ }^{41}$ Ibid. p. 431.
} 
Quanto ao Acetato de Ulipristal, pela teoria concepcionista, um dos efeitos deste fármaco seria ilícito, pois o efeito abortivo aconteceria quando o fármaco impede que o óvulo liberado dos ovários e fertilizado se aloje no útero, o que pela teoria concepcionista evitaria a gravidez como um meio abortivo.

Pela lógica da teoria concepcionista, ressalta-se que nenhum dos dois fármacos poderia ser comercializado uma vez que se a personalidade começa a partir da concepção ou seja, com o óvulo fecundado, e um dos efeitos de ambos as drogas é expulsar do útero o embrião (zigoto), a utilização dos fármacos seria considerada como método abortivo e não como contraceptivo de emergência.

$\mathrm{Na}$ teoria da personalidade condicionada, a qual fora adotada por Clóvis Beviláqua no artigo $3^{\circ}$ de seu Projeto de Código Civil, muito embora não tenha sido incorporada no artigo 4o do Código Civil de $1916^{43}$, muito embora não exista posicionamento registrado sobre tal fato, poder-se-ia destacar duas vertentes quanto ao estudo do Levonorgestrel e Acetato de Ulipristal à essa teoria.

Primeiramente, destaca-se que, assim como na teoria concepcionista, analisa-se que também apenas um dos efeitos da pílula do dia seguinte é abortivo, ou seja, quando esta impede que o óvulo já fecundado se instaure no útero, pois como a personalidade para essa teoria depende do nascimento com vida, nesse sentido, inviabilizar uma vida (considerando o início desta a partir da concepção) antes mesmo que o feto nasça é invalidar a própria teoria, pois haveria uma retirada da própria possibilidade de atribuição da personalidade.

Em contrapartida, e em segundo lugar, poderia se expor, no entanto, que os efeitos da pílula do dia seguinte não são abortivos para a teoria da personalidade condicionada porque se esta se atrela ao nascimento do feto com vida, e se este fato não acontece, não haveria porque conceder então direitos de personalidade ao feto ainda não nascido que foi expulso por um dos efeitos dos fármacos mencionados.

Assim, pela análise feita, não se busca invalidar uma ou outra teoria, apenas analisar os efeitos que os fármacos teriam perante tais, uma vez que os efeitos mencionados poderiam ir em direção oposta aos princípios do ordenamento jurídico brasileiro, dependendo da teoria a ser adotada.

Com efeito, não se discute aqui se o ordenamento jurídico concedeu ou não ao nascituro direitos de cunho patrimonial, pois resta óbvio pela dicção do artigo 542 do Código Civil que o nascituro pode ser beneficiário de doação, assim como de herança por legado pelo que revela o artigo 1799 também do Código Civil. $^{44}$

Não obstante, a legislação pátria previu, igualmente, o direito a alimentos para o nascituro ao publicar a

\footnotetext{
${ }^{42}$ Ibid. p. 429 .

${ }^{43}$ CHINELLATO, Silmara J. de Abreu. Estatuto jurídico do nascituro: a evolução do direito brasileiro. Coimbra: Almedina, 2009. p. 429. In CAMPOS, Diogo Leite de; CHINELLATO, Silmara J. de Abreu. Pessoa humana e direito. Coimbra: Almedina, 2009. p. 429.
} 
Lei no. 11.804/08, que prevê a possibilidade da gestante pleitear em juízo os alimentos gravídicos em favor do feto contra o suposto genitor do embrião a nascer, que deverá prestar alimentos ao nascituro e suposto filho gestado pela representante legal do feto.

Desta feita, torna-se impossível dizer que a lei não atribuiu direitos patrimoniais ao nascituro. Entretanto, no que se refere a direitos da personalidade, como a vida, a honra, a imagem e a integridade física, muito embora não se tenha uma previsão legal especifica prevendo tais direitos ao nascituro, uma vez que o artigo $2^{\circ}$ do Código Civil, com péssima redação, não deixa claro qual teoria adotou, abrindo margem para discussões sobre a aplicabilidade ou não da personalidade ao nascituro, infere-se que, por plausibilidade jurídica, se o nascituro possui direito de menor magnitude, como os direitos patrimoniais, certamente e automaticamente também seria portador de direitos de maior magnitude, como os direitos da personalidade.

Nesse sentido, tornar-se-ia impossível obstinar a validade e lógica da teoria concepcionista, que corrobora com os direitos atribuídos ao nascituro pelo ordenamento jurídico brasileiro. Entretanto, o que se busca aqui não é encontrar a teoria mais adequada para o direito, mas sim defender a posição de que, muito embora possa existir personalidade atribuída ao nascituro, isso não necessariamente corresponderia à atribuição do que seria o inicio da vida.

Seguindo a mesma lógica, torna-se necessário expor que ainda que se pressuponha uma vida do nascituro, pelos princípios da teoria concepcionista, defende-se aqui que a liberdade da mulher sobre o corpo, enquanto princípio básico de um Estado Democrático de Direito, seria hierarquicamente superior a uma suposta existência de vida intrauterina.

Não se busca invalidar qualquer teoria, seja ela a da personalidade condicionada ou a concepcionista, mas diferencia-se aqui que a atribuição de personalidade não significa, necessariamente, inicio de vida, ou sequer que é necessário, pela lógica do jusnaturalismo, pressupor a vida de alguém para depois lhe atribuir direitos, uma vez que estes são inatos e imanentes à humanidade como um todo, sendo desnecessário, por esta visão, se falar em identificação de vida para depois se atribuir direitos. ${ }^{45}$

\section{A SOLUÇÃO DE UMA COLISÃO ENTRE A LIBERDADE FEMININA E A VIDA DE UM FETO}

Que o direito à vida é imanente a qualquer ser vivo não restam dúvidas. Entretanto, assim como o direito

\footnotetext{
${ }^{44}$ CHINELLATO, Silmara J. de Abreu. Estatuto jurídico do nascituro: a evolução do direito brasileiro. Coimbra: Almedina, 2009. p. 429. In CAMPOS, Diogo Leite de; CHINELLATO, Silmara J. de Abreu. Pessoa humana e direito. Coimbra: Almedina, 2009. P. 428.

45 RADBRUCH, Gustav. Cinco minutos de filosofia do direito. Disponível em: <http://direitoavista.blogspot.c om.br/2011/04/cinco-minutos-de-filosofia-do-direito.html> Acesso em: 20. nov. 2015.
} 
à vida, o direito à liberdade também se trata de um direito imanente, que não pode ser retirado da esfera de direitos de qualquer individuo sob pena de retirar do individuo a própria razão de existir, uma vez que a existência não promove sentido sem a liberdade.

De fato, ao se falar em aborto, percebe-se uma colisão frontal entre esses dois princípios, que ao se colidirem trazem uma incógnita parcialmente insolúvel, pois essa colisão não promove uma resposta dizendo se um princípio se sobreporia ao outro, permanecendo a vida ou a liberdade.

Entretanto, no que se refere a situações de interrupção voluntária da gravidez, defende-se aqui que o princípio da liberdade se sobreporia ao princípio da vida, por ser um princípio que promoveria maior satisfação social quando deixa à escolha do sujeito, à quem o princípio é dirigido, o poder de decidir se prefere proceder ao aborto, seja por qual razão for, ou não.

Robert Alexy trouxe uma solução à colisão de princípios que se aplica diretamente ao caso aqui estudado. Quando dois princípios entram em colisão, chamados pelo mencionado autor de $P_{l}$ e $P_{2}$, um deles necessita ceder perante o outro. Porém, esclarece-se que isso não significa que o princípio que cedeu perante o outro se tornará eternamente inválido ou estará permanentemente em uma hierarquia inferior. Com efeito, a depender das circunstâncias de cada caso concreto, um princípio se sobreporá ao outro, e, assim, a dimensão a ser avaliada não é a da validade, mas, de fato, a dimensão do peso que cada princípio possui naquele determinado caso. $^{46}$

Desta feita, explica-se que a colisão dos princípios deve ser resolvida pela técnica do sopesamento. Torna-se necessário considerar as variáveis que se encontram em cada caso concreto para atribuir os pesos corretos a cada direito avaliando qual princípio deverá prevalecer, sendo que a verificação dos pesos dos princípios deverá se basear na máxima proposta por Alexy que revela que "quanto maior for o grau de não satisfação ou de afetação de um princípio, tanto maior terá que ser a importância de satisfação do outro". ${ }^{77}$

Seguindo esse caminho, após ocorrer o sopesamento dos princípios, torna-se possível encontrar um resultado em que um princípio precede o outro em determinadas circunstâncias, sendo que em outras, o princípio que fora preterido agora se sobrepõe sobre o princípio que antes houvera prevalecido.

Deste modo, exemplifica-se que na situação "A", $\mathrm{P}_{1}$ seria um princípio e $\mathrm{P}_{2}$ outro princípio em que naquela ocasião se demonstra diametralmente oposto. Assim, nessa oportunidade encontrar-se-ia que $\mathrm{P}_{1}>\mathrm{P}_{2}$. Em outro caso, poderia ser encontrada uma situação distinta em que $\mathrm{P}_{1}<\mathrm{P}_{2}$, especificando-se que a valoração dos princípios dar-se-ia de caso a caso, sem que houvesse uma hierarquia fixa a condenar um princípio a ser maior ou menor que o outro eternamente.

\footnotetext{
${ }^{46}$ ALEXY, Robert. Teoria dos direitos fundamentais. Trad. Afonso da Silva. Sa o Paulo: Malheiros, 2008. p. 93.

${ }^{47}$ Ibid.p. 167.
} 
Portanto, busca-se aqui, ao resolver a colisão de princípios entre o direito à liberdade e o direito à vida, fazer a mesma análise, ou seja, em determinadas situações, o direito à liberdade, consubstanciado, nesse caso, no aborto, se sobreporia ao direito à vida do feto, ou seja, Liberdade $\left(\mathrm{P}_{1}\right)>\operatorname{Vida}\left(\mathrm{P}_{2}\right)$. Cita-se como exemplo a esta situação a possibilidade de aborto até a vigésima sexta semana de gestação, critério adotado por grande parte dos países europeus, uma vez que ainda não há tronco cerebral nem córtex formado ainda no feto ${ }^{48}$, constatando assim, ausência de vida por critérios médicos também utilizados para verificação de ausência de vida em pessoas vivas.

Seguindo a lógica de Alexy, em outra situação, i.e., quando a gestação se encontrar cronologicamente acima da vigésima sexta semana, o princípio do direito à vida $\left(\mathrm{P}_{2}\right)$ se sobreporia ao princípio da liberdade $\left(\mathrm{P}_{1}\right)$, ou seja, (Liberdade) $\mathrm{P}_{1}<\mathrm{P}_{2}$ (Vida), desta feita, solucionar-se-ia as controvérsias vinculadas à questão do aborto.

Ademais, a permissibilidade do aborto se trataria de uma norma aberta, com abstração plena e geral, porém de eficácia restringível, pois muito embora tivesse operabilidade erga omnes, o destinatário real dessa norma seria aquele que efetivamente optasse por realizar o aborto, porque acredita que a vida não começa na concepção ou porque acredita que até a vigésima sexta semana ainda não há vida intrauterina.

\section{A REGULAÇÃO ATUAL DO ABORTO NO BRASIL: UM DESFAVOR A SAÚDE PÚBLICA E A AUTONOMIA FEMININA}

O Sistema Penal Brasileiro tipificou a conduta de abortar em três modalidades criminais, primeiro tipificando a conduta da mulher que pratica o aborto em si mesma ou consente que este seja praticado por outrem, em segundo plano tipificou a conduta do terceiro que pratica o aborto sem consentimento da gestante e por último, recaiu em redundância legislativa expondo que o terceiro que comete o ato de abortar com o consentimento da gestante também comete crime, o que já havia sido evidenciado em tipificação anterior. ${ }^{49}$

Por razões óbvias, o crime tipificado no artigo 125 do Código Penal Brasileiro possui plausibilidade jurídica uma vez que o dano à gestante, e possivelmente ao feto, é evidente pela clara ausência de voluntariedade da gestante em ter o aborto praticado contra si. Tal ato ensejaria, com clareza, reflexos cíveis, criminais e até administrativos, a depender de onde o crime ocorresse.

Entretanto, os crimes tipificados nos artigos 124 e 126 do C.P. trazem reflexões maiores a seu respeito, justamente por não existir no ordenamento jurídico brasileiro a conceituação expressa de quando começa a vida. Assim, a voluntariedade em praticar o aborto ou consentir que alguém o provoque, não deveria ser necessariamente um ilícito penal ou civil, pois carece de plausibilidade a proteção de uma suposta vida uterina em

\footnotetext{
${ }^{48}$ Bioethcis and law observatory. Document on voluntary interruption of pregnancy. Barcelona, april 2008. Disponível em <http://www.ub.edu/fildt/revista/pdf/RByD14_Interrupcion.pdf>. Acesso em 20. nov. 2015.
} 
que nem se sabe ao certo quando esta efetivamente começa em termos biológicos e não teológicos ou moralistas.

Ademais, há que se falar que a criminalização do aborto apenas atrapalha uma politica pública sanitária, pois a interrupção voluntária da gravidez já é uma realidade no país, com clínicas clandestinas que, no anonimato e na ilegalidade inconsistente, tentam demonstrar o respeito à autonomia da mulher quando permite a essa escolher o melhor momento para levar a gestação à frente baseando-se, com razão, no princípio do livre planejamento familiar.

De fato, permanecer criminalizando o aborto quando existe a vontade da mulher em não ter o filho, apenas aumenta a possibilidade de morte das gestantes juntamente aos fetos em razão da clandestinidade e da falta de preparo e condições das clínicas que oferecem esse tipo de serviço. Deve ser ainda levado em consideração que a falta de condições desses locais em prestar a assistência ou a realização do aborto não impede que milhares de jovens grávidas procurem essas clínicas para abortarem, e, por consequência, recair sobre a tipificação ineficaz dos artigos 124 e 126 do Código Penal Brasileiro.

Conforme mencionado, no Brasil há permissão para que se proceda ao aborto apenas quando a vida da mãe está em risco e não há outro meio de salvá-la senão praticando-o, em caso de gravidez resultante de estupro, e mais recentemente, após decisão proferida pelo $\mathrm{STF}$ na $\mathrm{ADPF}$ no. 54 , em caso de gravidez de feto anencefálico. ${ }^{50}$

O maior problema está no fato de que grande parte, ou a maioria dos abortos clandestinos ocorrem justamente porque não se encaixam nos casos de permissibilidade abortiva do Código Penal, e por isso necessitam recorrer à clandestinidade e ilegalidade para poderem efetivar um direito à saúde, e, acima de tudo, o princípio da autonomia sobre o próprio corpo.

Torna-se importante reiterar que muito embora o Estado permita o aborto de feto proveniente de estupro, não o permite em casos de gravidez involuntária por ato sexual consentido, seja porque não houve utilização de um contraceptivo ou porque este não funcionou.

Ao analisar ambas as situações, torna-se possível concluir que o Estado perante um caso de estupro escolhe tutelar a liberdade da vítima em detrimento da vida do feto proveniente de violência sexual. Entretanto, o mesmo Estado, perante um caso de gravidez involuntária por ato sexual consentido, prefere tutelar a vida intrauterina, ainda que indesejada, do que a liberdade da mulher, como se a vida intrauterina possuísse valores distintos quando existisse uma gravidez resultante de estupro e outra resultante de falha ou ausência de método contraceptivo.

Claro está que se trata a mesma situação objetiva com dois pesos, e duas medidas. Por isso, indaga-se: qual o motivo para desvalorizar legalmente a vida de um feto cujo genitor é um estuprador e valorizar legalmente a

\footnotetext{
${ }^{49}$ Os crimes estão respectivamente previstos nos artigos 124, 125 e 126 do Código Penal Brasileiro.

${ }^{50}$ As hipóteses de possibilidade de aborto estão previstas respectivamente no artigo 129, I e II do Código Penal Brasileiro, e na $\mathrm{ADPF} n^{\circ} .54$.
} 
vida de um feto cujo genitor utilizou erroneamente ou não quis utilizar um método contraceptivo? Trata-se de mera moralidade intrinsecamente axiológica do legislador brasileiro, seja ela teológica ou social, cujas bases se pautam no suposto ato de que abortar é um ato cruel porque supostamente tiraria a vida de um ser em formação.

É importante perceber que em ambos os casos a gravidez é involuntária, o que difere uma de outra é a ausência ou não de violência para a realização do ato sexual que resulta na gravidez. De fato, é como se o Estado estivesse punindo a mulher que consentiu em realizar atividade sexual ao não deixá-la optar por ter o filho ou não. Em uma análise clara, tal situação se coloca como se o Estado dissesse às mulheres "se você for estuprada, pode abortar, mas se você consentir com o ato, é obrigada a ter o filho". Provoca-se novamente ao raciocínio de que o ordenamento jurídico brasileiro está punindo o ato de praticar atividade sexual que, por alguma razão, resulta em gravidez indesejada.

\section{Cytotec (Misoprostol): uma realidade abortiva}

O misoprostol, conhecido como Cytotec, é a versão sintética da prostaglandina ${ }^{51}$. É um fármaco que deve ser prescrito e utilizado no tratamento e prevenção de úlcera do estômago. Todavia, no Brasil, a droga supracitada também é utilizada para se alcançar uma finalidade, até o momento, ilegal, ou seja, o aborto, até mesmo porque a comercialização deste fármaco foi proibida no Brasil desde 2005, muito embora em algumas capitais são encontrados no mercado negro facilmente..$^{52}$

A função oficial deste fármaco no Brasil foi desvirtuada exatamente em razão do grande número de gravidez indesejada e da criminalização do autoaborto e do aborto provocado por terceiros com an uência da gestante. Dessa forma, o Cytotec se transformou em um método abortivo utilizado por jovens que não querem levar a gravidez adiante, mas também não podem abortar, uma vez que essa prática social ainda é crime e, por isso, qualquer ato abortivo acaba ocorrendo no anonimato.

A escolha pelo Cytotec como método abortivo é, de fato, uma escolha feita por mulheres desesperadas que pertencem à classe média baixa ou pobreza cujo único meio de tentar o aborto é pelo uso do Cytotec cujo valor de aquisição é consideravelmente menor do que os valores pagos por gestantes em clínicas clandestinas.

O risco de se tentar o aborto pelo uso de Cytotec pode causar graves danos à saúde da mulher, e as mulheres que buscam o Cytotec com a finalidade abortiva, mesmo tendo ciência do risco de sua utilização, preferem arriscar a própria saúde, vida, integridade física e até cometer um ato ilícito, correndo o risco de sofrer as

\footnotetext{
51 MINISTÉRIO DA SAÚDE: Misoprostol. Disponível em: <http://bvsms.saude.gov.br/bvs/publicacoes/protocolo_utilizacao_misoprostol_obstetricia.pdf > Acesso em: 20. nov. 2015. 52 JUNIOR, Paulo Roberto. De uso proibido no Brasil, abortivo é encontrado com facilidade em camelôs do Centro. Disponível em: <http://oglobo.globo.com/rio/de-uso-proibido-no-brasil-abortivo-encontrado-com-facili dade-em-camelos-do-centro-15495646> Acesso em: 20. nov. 2015.
} 
sanções penais do que manter a gravidez.

Mediante este quadro social de uso indevido de uma droga indiretamente abortiva, uma vez que sua finalidade terapêutica não é abortiva, não restam dúvidas de que a prática do aborto no Brasil é usual e tem tomado maiores proporções com o aumento da banalidade das relações interpessoais baseadas em tecnologias de redes sociais contemporâneas e aplicativos que promovem a promiscuidade com ar de normalidade.

Desta feita, torna-se visível que a criminalização do aborto no Brasil traz efeitos negativos à população feminina que sofre com o problema da gravidez indesejada e nada pode fazer para dar uma solução viável à gravidez que não seja a manutenção desta. Assim, com um cenário não receptível à liberdade feminina, mulheres arriscam a saúde consumindo o Cytotec.

\section{REFLEXÕES PARA A DESCRIMINALIZAÇÃO DO ABORTO}

A realidade social brasileira já demonstra estar inclinada à efetivação da prática do aborto, muito embora este ainda não seja permitido no país. Mediante isto, torna-se necessário a análise de algumas questões que demonstram a necessidade de descriminalização do aborto no cenário brasileiro para que se evite as trágicas consequências de sua criminalização.

Primeiramente, observa-se que existe uma incompatibilidade no ato de se criminalizar o aborto se comparado com o comportamento social frequente, destacando-se a ineficiência e ineficácia da lei penal ao criminalizar comportamentos usuais e aceitos por parte significativa da população. De fato, a lei penal não possui eficácia contra atos abortivos e, como consequência, verifica-se o crescimento de pessoas a buscar por ajuda ilegal e não qualificada, colocando a vida e a saúde em risco.

No que se refere a acordos internacionais, o Brasil é um dos países que figuram enquanto signatário do Sistema de Proteção dos Direitos Humanos das Mulheres, o qual prevê a possibilidade da realização do aborto como método a evitar a gravidez indesejada. E muito embora o país seja um signatário, a política pública de prática ao aborto ainda não foi implementada no país.

Em segundo lugar, deve-se perceber que existe igualmente uma imensa incompatibilidade entre o ato de se criminalizar o aborto quando esta criminalização se trata de tornar dominante uma determinada concepção moral, ou seja, a criminalização do aborto permanece no sistema jurídico brasileiro em razão de moralismos arraigados a uma ideia emblemática de que se trata de um mal a um ser humano, ou, por vezes, atribui-se ainda o critério teológico de que o aborto é uma espécie de pecado.

Fato é que não se pode penalizar uma conduta criminalmente, ou até mesmo civilmente, em razão de moralismos ou crenças religiosas que visam destruir o principio da laicidade estatal. Não há razão para em um país que se intitula laico, defender ou ter partidos políticos que colocam a vida como o princípio supremo, quase como 
uma obrigação, sem analisar questões como a saúde pública em razão de atos abortivos.

Outro ponto importante a ser revelado se trata do princípio do Estado Penal Mínimo e da Ultima Ratio. Nesse sentido, o direito penal brasileiro, pelos princípios estruturantes mencionados, não deveria se preocupar em punir uma conduta aceita socialmente, com grande número de adeptos que praticam um ato típico, ilícito e punível à luz de uma lei obsoleta. A criminalização não funciona, e por assim ser, o direito penal não deveria intervir em atos socialmente aceitos, e ainda que intervisse deveria ser o último direito a participar na regulação de um fato.

Inobstante às questões mencionadas, existem dados sobre o aborto praticado de forma insegura no Brasil, os quais foram publicados pelo Ministério da Saúde e Alan Guttmacher Institute apontando que:

3,65 abortos por 100 mulheres de 15 a 49 anos; Perfil das mulheres: jovens menores de 20 anos e primigestas; 20\% das mortes maternas no Maranhão (1987 - 1991); Salvador - BA, $1^{a}$ causa de morte materna desde 1990; $3^{\text {a }}$ causa de morte materna em São Paulo - 9,9\%; $5^{\mathrm{a}}$ causa mais frequente de internação; $2^{\circ}$ procedimento obstétrico mais realizado; 250 mil internações pelo SUS para tratamento das complicações do abortamento. ${ }^{53}$

Nota-se pelos dados revelados que a ilegalidade do aborto não tem impedido nem as mulheres de o praticarem nem os terceiros que o praticam, mas apenas piorado as condições em que são realizados e agravado os riscos inerentes a essa prática, como a possibilidade de esterilidade ou até mesmo a morte.

\section{REFLEXÕES FINAIS}

O presente trabalho procurou trazer à baila da relação entre bioética e direito uma análise voltada às novas formas científicas de se evitar a gravidez, conhecidas como contraceptivos de emergência. Em razão da relevância do tema, estuda-se, efetivamente, os efeitos biológicos com consequências jurídicas e sociais dos fármacos Levonorgestrel e Acetato de Ulipristal, conhecidos mundialmente como pílula do dia seguinte e EllaOne, respectivamente.

Procurou-se abordar, inicialmente, a origem de um dos problemas relacionado ao aborto está na consequência da cultura pós-moderna em que as relações humanas passaram a significar muito pouco ou quase nada, e em consequência da liquidez social e da volatilidade do afeto dentro das relações interpessoais, a incapacidade humana de se comprometer a um vínculo duradouro como a maternidade ou paternidade passou a gerar uma demanda maior pela busca do aborto.

Defende-se ainda no presente estudo que existe uma relação direta entre os papéis de gênero e a bioética, uma vez que as dominações sociais e imposições culturais são, de fato, voltadas à cada gênero. Nesse sentido, impõe-se condutas e obrigações à mulher contemporânea que se vê obrigada moral e culturalmente a ser mãe, em razão de seu gênero, não podendo expor a liberdade de optar por escolher as regras quanto ao seu corpo. 
Ademais, procurou-se apontar criticas ao Projeto de Lei no. 5.069/2013 por ser um atentado contra a liberdade substancial feminina uma vez que o projeto visa tipificar como crime contra a vida o anúncio de meio abortivo, prevendo ainda penas específicas para quem induz a gestante à prática de aborto. Assim, demonstrou-se que qualquer tipo de fármaco como o Levonorgestrel ou o Ulipristal que possuíssem efeitos abortivos teriam que ser proibidos no Brasil. Não obstante, por lógica legalista, a permissibilidade do aborto em caso de estupro também seria extirpada do ordenamento legal, o que configura-se como um absurdo e um completo atentado contra a liberdade da mulher.

Buscou-se defender, igualmente, que os fármacos Levonorgestrel ou o Acetato de Ulipristal não são abortivos, mas meros contraceptivos de emergência, uma vez que não se considera, para efeitos de escolha entre a liberdade da mulher e o direito à vida do feto, a concepção como ponto delimitador de quando se começa a vida. De fato, como não existe ainda uma definição exata de quando a vida começa, tal ponto se trata de uma questão de opinião, e por assim ser, prega-se a favor da liberdade de escolha da mulher em levar ou não adiante uma gestação pelo simples fato de que uma norma aberta respeitaria ambas as opiniões, atendendo os dois públicos, pró-vida e pró-liberdade.

Fez-se a análise dos efeitos dos fármacos Levonorgestrel e Acetato de Ulipristal perante as teorias da personalidade, dentre elas a teoria natalista, a concepcionista e a da personalidade condicionada, verificando-se que para a teoria concepcionista ambos os fármacos poderiam ser considerados potencialmente abortivos, enquanto que para a natalista nenhum daqueles o seriam. Já para a teoria da personalidade condicionada, verificou-se dois pontos, sendo que para esta ambos os fármacos poderiam ser ou não considerados potencialmente abortivos.

Entretanto, buscou-se expor, igualmente, que o presente estudo não tenta desconsiderar o valor de uma teoria frente à outra, mas demarcar que independentemente da teoria adotada, o conflito entre vida e liberdade ultrapassaria a fronteira das teorias, entrando em uma batalha principiológica, na qual optou-se por deixar claro que a solução sobre a colisão dos princípios liberdade e vida deve obedecer a regra proposta por Robert Alexy, ou seja, a questão deve ser enfrentada caso a caso, sem que exista efetivamente um princípio maior que o outro hierarquicamente no ordenamento jurídico brasileiro.

Procurou-se argumentar ainda que a atual regulação do aborto no Brasil é evidentemente um desfavor à saúde pública e à autonomia feminina, uma vez que as mulheres brasileiras sofrem em clínicas clandestinas e com medicamentos potencialmente lesivos à saúde ou em alguns casos fatais, como o Cytotec. Trata-se de uma realidade existente com a qual o legislador brasileiro não sabe lidar nem quer enfrentar em razão de uma sociedade arraigada em uma cultura moralista e teológica.

\footnotetext{
${ }^{53}$ TORRES, José Henrique Rodrigues. Aborto e constituição. 1. ed. São Paulo: Estúdio Editores.com, 2015. p. 27.
} 
Por último, buscou-se apresentar reflexões para a descriminalização do aborto, demonstrando que a criminalização não é eficaz para impedir a conduta assim como é indevida, pois não representa uma vontade social nem respeita os princípios penais do Estado Mínimo e da Ultima Ratio.

De maneira geral, buscou-se analisar e demonstrar que a utilização dos fármacos como contraceptivo de emergência não seriam métodos abortivos, e muito além disso, cumprem uma função importante no controle da saúde pública e como ferramenta importante para as vítimas de estupro que contam com tais fármacos para efetivarem seu direito à liberdade de se ter um filho ou não, muito embora o Acetato de Ulipristal não seja comercializado no país, apenas o Levonorgestrel.

Em definitiva, buscou-se defender a ideia da análise referente à colisão de princípios pela teoria de Robert Alexy para se solucionar o conflito entre possibilidade de aborto versus o direito à vida, optando pela defesa de que o aborto deve ser permitido em alguns casos em que a liberdade substancial feminina deve prevalecer.

\title{
CONTRACEPTIVES OF EMERGENCY AND ABORTION IN BRAZILIAN CRIMINAL LAW: A BIOETHICAL ANALYSIS
}

\begin{abstract}
This article aims to analyze the relation between women's freedom and the right to life, studying the effects of emergency contraceptives such as Levonorgestrel and Ulipristal Acetate, in a bioethical analysis about the biological, social and legal contents brought by the mentioned drugs. Nevertheless, the personality theories are analyzed linked to the effects of the emergency contraception to promote and verify if the contraception would be mere emergency contraceptives or abortifacients. As it regards the analysis by the personality theories, the study carried out here seeks to solve the collision of existing principles when there is a contradiction between the life principle and the substantial female freedom over her body, weighing principles case by case. Furthermore, this study sought to bring an analysis of how the criminalization of abortion is harmful, and thus ineffective to the Brazilian reality, once the female society seeks for its social emancipation regarding issues concerning their own body as a form to actualize the right to health, especially public health. It is also presented in this article the Brazilian reality, which includes the use of Cytotec, a drug even banned from Brazil that can still be found and acquired illegally on the black market. Finally, using the deductive method, this study seeks to analyze possible civil effects that would be caused by abortion, in order to defend the decriminalization of abortion.
\end{abstract}

Keywords: Levonorgestrel. Ulipristal Acetate. Abortion. Freedom. Life.

\section{REFERENCIAS}

ALEXY, Robert. Teoria dos direitos fundamentais. 1. ed. trad. Afonso da Silva. Sa o Paulo: Malheiros, 2008.

BAUMAN, Zygmunt. Amor líquido: sobre a fragilidade dos laços humanos. Rio de Janeiro: Zahar, 2004. 
BEAUVOIR, Simone de. O segundo sexo. 6. ed. Rio de Janeiro: Nova Fronteira, 1980.

BRAZIL-GUIDELINES 2015: Acetato de ulipristal, Levonorgestrel. Disponível em:<http://www.cecinfo.org/custom-content/uploads/2015/05/Brazil-Guidelines_2015.pdf Acesso em 27. ago. 2015 .

BULASMED: Levonorgestrel. Disponivel em:<http://www.bulas.med.br/p/levonorgestrel. Acesso em 27. ago. 2015

CÂMARA DOS DEPUTADOS. Projeto de Lei no. 5069/2013. Disponível em: <http://www2.camara.leg.br/proposicoesWeb/fichadetramitacao?idProposicao=565882> Acesso em: 08. nov. 2015.

CHINELLATO, Silmara J. de Abreu. Estatuto jurídico do nascituro: a evolução do direito brasileiro. Coimbra: Almedina, 2009. p. 428-429. In CAMPOS, Diogo Leite de; CHINELLATO, Silmara J. de Abreu. Pessoa humana e direito. Coimbra: Almedina, 2009.

CONSELHO FEDERAL DE MEDICINA. Resolução no. 2.013/2.013. Disponível em: <http:/ www.portalme dico.org.br/resolucoes/CFM/2013/2013_2013.pdf>Acesso em: 20. nov. 2015.

CRUZ, Luis Carlos L. da. O aborto do dia seguinte. Disponível em: <http://www.providaan apolis.org.br/index.php/todos-os-artigos/item/343-o-aborto-do-dia-seguinte> Acesso em 19. nov. 2015.

CYCLOPAEDIA. Ulipristal. Disponível em: <http://pt.cyclopaedia.net/wiki/Ulipristal> Acesso em: 19. nov. 2015.

DWORKIN, Ronald. Levando os direitos a sério. São Paulo: Martins Fontes, 2002.

LUNARDI, Soraya R. G. O direito é masculino. Estadão Noite, em 17.11.2015. Disponível em: $<$ http://www.unesp.br/portal?hc_location=ufi\#!/noticia/20033/o-direito-e-masculino/ Acesso em: 10. dez. 2015

MINHA VIDA. Uso de roacutan na gravidez e amamentação. Disponível em: <http://www.minhavida.com.br/saude/bulas/20-roacutan-capsula-mole/gravidez-amamentaca o> Acesso em: 20. nov. 2015.

MINISTÉRIO DA SAÚDE. Anticoncepção de Emergência: perguntas e respostas para profissionais de saúde/Ministério da Saúde, Secretaria de Atenção a囚 Saúde. Brasília: Ministério da Saúde, 2005. Disponível em: $<$ http://bvsms.saude.gov.br/bvs/publicacoes/cader no3_saude_mulher.pdf> Acesso em: 19.nov. 2015.

MINISTÉRIO DA SAÚDE: Misoprostol. Disponível em: <http://bvsms.saude.gov.br/bvs/publicacoes/protocolo_utilizacao_misoprostol_obstetricia.pdf > Acesso em: 20. nov. 2015.

NETDOCTOR. EllaOne: ulipristal acetate. Disponível em: <http://www.netdoctor.co.uk/medicines/sexualhea lth/a8735/ellaone-ulipristal-acetate/> Acesso em 19. nov. 2015. 
PINHEIRO, Pedro. Pílula do dia seguinte: como tomar, eficácia e efeitos. Disponível em: <http://www.mdsaude.com/2012/08/pilula-dia-seguinte.html> Acesso em: 19. nov. 2015.

RADBRUCH, Gustav. Cinco minutos de filosofia do direito. Disponível em: <http://direitoavista.blogspot.c om.br/2011/04/cinco-minutos-de-filosofia-do-direito.html> Acesso em: 20. nov. 2015.

RAMPIN, Talita T. Dias. Bioética, aborto e processo: desafios de um novo campo de estudo. In MARCHETTO, Patricia Borba et al. Temas fundamentais de direito e bioética. São Paulo: Cultura Acadêmica: Editora UNESP, 2012.

SANDEL, Michael J. O que o dinheiro não compra: os limites morais do mercado. Rio de Janeiro: Civilização Brasileira, 2012.

SANTOS, Fabiano. Para que serve o hímen? Disponível em: <http://fajacnoticias.blogspot.c om.br/2014/11/para-que-serve-o-himen.html> Acesso em: 03. nov. 2015.

SILVA, Karlla Patrícia. Qual a função biológica do hímen? Disponível em: <http:// diariodebiologia.com/2009/10/qual-a-funcao-biologica-do-himen/> Acesso em: 03. nov. 2015.

TORRES, José Henrique Rodrigues. Aborto e constituição. 1. ed. São Paulo: Estúdio Editores.com, 2015.

WORLD HEALTH ORGANIZATION. Emergency contraception. Disponível em: <http://www.who.int/me diacentre/factsheets/fs244/en/> Acesso em: 19. nov. 2015.

Trabalho enviado em 17 de julho de 2016.

Aceito em 26 de janeiro de 2017. 